\title{
Working Mothers in Finland: A Cross- Country Comparison of Work to Family Interference, Work Characteristics and Satisfaction with Life
}

SIRPA WECKSTRÖM, M.Sc. (Econ.), M.Soc.Sc., Doctoral Student Department of Social Research / Social Policy and Social Work, University of Turku, Finland

\section{Abstract}

In this study it was examined whether work-related experiences of Finnish mothers are different from work-related experiences of mothers in 11 other European countries. The data was based on European Social Survey, round 2, conducted in the years 2004-2005. Descriptive statistics and ordinal regression analysis were used to assess the outcomes. Work to home interference was not especially frequent among mothers in Finland. However, interference that comprised other family members was more common than in the other countries investigated. With regard to work characteristics, Finnish mothers differed both negatively and positively from mothers in the other countries. Long working hours increased time-based interference from work to family members. Time pressure at work increased both time- and strain-based interferences. Social support from co-workers decreased strain-based interference. Work to family member interferences, especially strain-based interference, were negatively connected to life satisfaction. Both working and non-working mothers in Finland appeared to be satisfied with their life.

Key words: mothers, work-family interference, work characteristics, life satisfaction, childcare policy

\section{Introduction}

Compared to mothers in many other European countries, mothers in Finland have a long tradition of undertaking paid work. As far back as the 1970s, and increasingly in the 1980s, even mothers who had young children frequently worked outside the home (Kauppinen-Toropainen, Haavio-Mannila, Kandolin and Simonsuuri-Sorsa 1983). In the 21st century, the employment rate for Finnish mothers was still among the highest in Europe (OECD 2007). Since the 1990s, however, a considerable part of mothers have stayed at home with their newborn child for relatively long periods, typically until the child is 1.5 to 3 years old (OECD 2005; Lammi-Taskula, Salmi and Parrukoski 
2009). In many other European countries, the number of mothers who worked despite having such young children increased during this period.

The diverging trend shown in Finland is connected to a child home care allowance, i.e., a benefit that can be obtained as an alternative to a public childcare place, covering a period from the end of the parental leave period until the child is 3 years old. The allowance provides financial support for taking care of children at home for a prolonged period. On the other hand, mothers have also chosen this option because of problems in finding a job, especially when jobs have been scarce, such as during the recession of the early 1990s (Lammi-Taskula 2004; Lammi-Taskula et al. 2009). Furthermore, a study of mothers who stayed at home when the child was two years old indicated that mothers frequently justified a prolonged home care period by its importance for the child (Salmi, Lammi-Taskula and Närvi 2009). A negative perception of work-life, such as a hectic pace or burdensome work, was also mentioned by many mothers. Recent marked changes in the nature of work render the latter explanation interesting.

Starting in the late 1980s, there has been a wide scale rethink of the management style in public sector organisations, which has been strengthened by the recession of the 1990s and globalization related increase in competition. Ideals such as effectiveness and efficiency, as well as accountability in terms of results, were adopted from the management philosophy of private sector organisations (Hood 2005; Koivumäki 2005). Values in the private sector also became even more challenging than before. There are a few reasons to suggest why Finnish mothers may have been affected by these changes in the workplace more than mothers in Europe in general. Firstly, a considerable part of women in Finland work in public sector organisations. Secondly, the recession was especially deep in Finland, and the low unemployment rates and relatively favourable relationship between the permanent and temporary work contracts of pre-recession times were not attained again after the recession (OECD 2010; Statistics Finland 2005 and 2011).

This study investigated the way in which mothers perceive their work, with the primary aim of assessing whether there are particular aspects associated with the work domain in Finland that could have increased the attraction of long home care periods. The experiences of Finnish mothers are compared with those of mothers in other European countries. Experiences are examined in terms of work to family interference and selected work characteristics. With regard to the latter, the focus is on working hours and such characteristics that have changed in a way that could have hindered the successful reconciliation of motherhood with paid work. The approach of this study is complemented by directly asking mothers whether they are satisfied with their lives.

The present study is based on Europen Social Survey (ESS) data for the years 2004-2005. In addition to Finland, the other countries included are Austria, Belgium, Denmark, France, Germany, Greece, the Netherlands, Portugal, Spain, Sweden and the 
UK. Work-related experiences have in previous cross-country comparisons typically been charted for all employees, or separately for women and men (e.g. Boye 2011; Paoli and Merllié 2001; Steiber2009). Wide scale comparisons regarding in particular mothers of relatively young children are, however, scarce. In the present study, only those mothers who had children under 13 years old were included.

\section{Investigated aspects}

\section{Work to family interference}

Work-family interference is experienced when pressures from work and family roles are mutually incompatible, so that engaging in one role makes it difficult to engage in the other role (Greenhaus and Beutell 1985). A recent study indicates that work-family interference is more common in Finland compared to the average in Europe (Boye 2011, also based on ESS 2004-2005 data). A closer look is taken here on work to family interference. Work to family interference occurs when time devoted to a work role makes it difficult to function in a family domain role, strain experienced in a work role impedes an effective functioning in a family domain role, or behavioural requirements in a work role are incompatible with behavioural requirements in a family domain role. This investigation focuses on time and strain based interferences, as reported by mothers.

If a person encounters a stressful life situation, one way to cope is by use of a withdrawal behaviour (Lazarus and Folkman 1984). Any substantial work to family interference could thus increase the motivation to stay at home for a somewhat longer period. When other family members, especially children, suffer from detrimental work-related effects, a prolonged period at home with a child (or children) could become a very appealing option. Therefore, a division has been made in this study into individual interference and interference relating to family members. Individual interference refers to interference related to the home domain in general, whereas interference relating to family members refers to situations in which detrimental effects comprise other family members or activities with them.

The main aim here is to clarify to what extent in particular mothers in Finland differ from mothers in the other countries studied with regard to work to family interference, and what is the type or quality of the eventual excess interference.

\section{Characteristics of work}

Finnish mothers typically work full-time, whereas mothers in many other European countries often choose part-time work (Eurostat 2005). Part-time work has been connected to better compatibility of working hours with family obligations and a lower level of work to family interference, as compared to full-time work (e.g. Fagan and Burchell 2002; van Rijswijk, Bekker, Rutte and Croon 2004). Moreover, long working hours have been associated with work to family interference and psychological 
distress (Major, Klein and Ehrhart 2002). Atypical working hours may also be a hindrance for a successful reconciliation between motherhood and paid work (e.g. Fagan and Burchell, 2002). The proportion of women in Finland working outside the regular dayshift has increased during the last few decades (Tammelin 2009). On the other hand, these days employees have greater opportunities to decide when to start and when to finish work and this should facilitate the reconciliation of the two life domains. As well as weekly working hours, both atypical and flexible working hours are considered in this study.

In the last few decades, a clear intensification of work has occurred (Lehto and Sutela 2008; Paoli and Merllié 2001; Parent-Thirion, Macías, Hurley and Vermeylen 2005). In earlier cross-country comparisons time pressure, or high work intensity, has been more common in Finland than on average in Europe (Paoli and Merllié 2001; ParentThirion et al. 2005). The existence of time pressure at work has been associated with, for example, stress and fatigue (Paoli and Merllie, 2001). Stress related to a greater intensity of work can be particularly high if great quantitative demands are combined with low, or decreasing, control over the pace of work, or low or decreasing job autonomy (Eurofound 2007). The aspects considered in the present study are (in)sufficient time to have a job done, a possibility to change the pace of work and a possibility to participate in organisation of work.

An additional change during the last few decades has been the substantial increase in job insecurity (e.g. Cooper 2007). Job insecurity refers to a situation in which the role as an employee is threatened due to a work contract with a non-permanent duration or a fear of layoff from a current job. Negative correlations have been observed between both types of insecurities and the psychological wellbeing of an individual (Kompier, Ybema, Janssen and Taris 2009; Mauno 1999; Scherer 2009; Virtanen, Vahtera, Kivimäki, Pentti and Ferrie 2002). These insecurities also appear to have detrimental effects on home life. Contractual job insecurity has been connected to conflicts with the spouse (Scherer 2009), whereas subjective insecurity has been connected to difficulties in coping with the role of a mother (Mauno 1999).

In an international comparison, temporary work contracts are common among women in Finland (Lehto, Lyly-Yrjänäinen and Sutela 2005). Among the aims of this study are finding out to what extent work contracts of mothers in Finland differ from work contracts of mothers in the other countries included, and whether this difference is reflected in how job insecurity is subjectively assessed. An opportunity exists here to consider the importance of job insecurity (as well as other work characteristics included) on experienced interference from work to home. An additional work-related condition that is included is the social support available for an employee. Stressful experiences at work are more difficult to cope with if no help is available from colleagues or supervisors (Eurofound 2007: 3). 


\section{Life satisfaction}

Life satisfaction is one among concepts that are presumed to reflect conditions of good life. It refers to a judgmental process in which an individual compares her/his life circumstances to her/his own standards. To the degree that conditions match with these standards the person reports high life satisfaction (Pavot and Diener 1993; Shin and Johnson 1978). In the present study, life satisfaction is used to describe how working mothers feel about their life as a whole. In order to improve the understanding of the importance of work-related conditions in particular, apart from conditions common to all mothers in the countries studied, non-working mothers are included in the evaluation. Mothers who do not participate in paid work avoid possible negative experiences at work, as well as any pressures that arise from combining family and work roles. However, these mothers miss out on positive experiences at work and possible positive spillover between the roles. A positive spillover exists when performance in one role is improved by resources gained in the other role or by positive affects related to that role (Greenhaus and Powell 2006).

The importance of work to family interference on life satisfaction has not been previously much investigated. In the first European quality of life survey it was found that work to family interference had only a weak negative effect on life satisfaction (Wallace, Pichler and Hayes 2007). However, in another study of several European countries it was found that work-family balance was an important determinant of life satisfaction. Those women who experienced work-family interference were less satisfied with their life than were housewives (Matysiak, Pailhé, Solaz and Vignoli 2010). The importance of work-family balance has also been observed in a study of young adults in Finland (Martikainen 2009). The highest levels of life satisfaction were found among those women who had a job that did not require them to compromise their loyalty to their family. These women were also typically satisfied with their working conditions. Overall, it has been found that perceptions of working conditions (e.g. perceived job security) explain more in terms of life satisfaction than do employment settings, such as hours of work (Wallace, Pichler and Hayes 2007).

A significant advantage related to work participation is financial independency. Nonparticipation in work increases dependency on one's spouse for financial security, and also eventually increases financial hardship within the family. It has been shown that financial circumstances, especially financial hardship, have a marked impact on a person's life satisfaction (Diener, Oishi and Lucas 2003; Kainulainen 1998).

It can be concluded that a successful reconciliation of motherhood and paid work should improve a mother's life satisfaction. An aspect that might, however, moderate the effect of a work-care situation on life satisfaction is the possibility of choosing a preferred work-care situation. A study among German mothers indicated that when non-participation, or working short hours, is a consequence of constraints set by 
family, it negatively influences a woman's life satisfaction (Berger 2009). The possibility of choosing a preferred work-care situation is markedly affected by childcare policies. Furthermore, childcare policies can directly improve the life satisfaction of mothers by providing financial support for mothers in different work-care situations, i.e. by providing monetary compensation for wage loss during a period of time spent at home caring for a child, and by lessening the monetary burden related to formal care outside the home.

With regard to both fields of childcare policies, Finland can be considered as generous. In Finland, as well as in the other two Nordic countries (Denmark and Sweden), the parental leave periods are covered by an earnings-related compensation. In the other countries investigated, only periods of maternity leave are related to a compensation that covers a considerable part of the loss of earnings. What differentiates Finland from Denmark and Sweden is the child home care allowance. Due to this benefit, Finnish mothers are facilitated to stay with their children at home for a much longer period than are mothers in Denmark and Sweden. In addition to Finland, Austria, Germany and France (for a part of the mothers) also provide a flat-rate monetary compensation for home care until a child is two or three years old. Mothers in these countries, especially in Austria and Germany, however, cannot choose between the various work-care situations as freely as can mothers in Finland. With the exception of the three Nordic countries, a lack of childcare restricts the possibilities of mothers to participate in (fulltime) paid work in all countries investigated in this study, although less so in Belgium and France (Bradshaw and Finch 2002; Gornick and Meyers 2003).

This section primarily aims to clarify how Finnish working mothers assess their life as a whole. Finnish working mothers are compared with Finnish non-working mothers and with working mothers in the other countries included. When assessing cross-country differences in mothers' life satisfaction, national differences in life satisfactions in general among individuals (e.g. Diener et al. 2003; Minkov 2009) should be taken into consideration. In addition to non-working mothers, the following reference groups were included in this study: working women with no children living in the same household, working fathers, all employees and all adults.

\section{Data and methods}

The data used in the present study were based on the ESS, Round 2, conducted during the years 2004 and 2005. The sample consisted of women aged 20 to 50 years who had a child or children (own, adopted, foster or their partner's) aged under 13 years living in the same household. A precondition for being classified as a working mother was that a mother had participated in paid work during the previous seven days. The number of working mothers was as follows: 139 in Finland, 137 in Austria, 122 in Belgium, 160 in Germany, 153 in Denmark, 89 in Spain, 183 in France, 157 
in the UK, 96 in Greece, 175 in the Netherlands, 164 in Portugal and 158 in Sweden. The present data indicate that working mothers in Finland had commonly prolonged their home care periods by using at least a part of the child home care allowance. Of working mothers in Finland, 70\% had taken care of their children at home more than two years. Compared to Sweden, a country with a closely corresponding number of children per mother, the clearest difference was seen in the percentages of those mothers who had spent more than four years at home; 30\% in Finland and 14\% in Sweden. A non-participation in work status was given to those mothers who reported housework and/or caring for children and did not report participation in paid work. A further precondition was that a mother was not unemployed. Other reference groups used in this study were working fathers and working women with no children living in the same household, who were in the same age range as the investigated mothers, all employees and adults.

Individual interference from work to home was measured by asking the respondents how often they keep worrying about work problems when they are not working, and how often they feel too tired after work to enjoy the things they would like to do at home. As regards interference related to family members, a division was made between time-based and strain-based interference. Time-based interference from work to family members was measured by asking the respondents how often their job prevents them from giving the time they want to their partner or family. Strain-based interference from work to family members was measured by asking the respondents how often they find that their partner or family gets fed up with the pressure of their job. There were five response alternatives for the questions regarding work to family interference: 'never', 'hardly ever', 'sometimes', 'often' and 'always'.

Working hours were measured by the total hours a respondent normally worked per week in the main job (including overtime). Regarding atypical working hours, respondents were asked how often their work involves working in evenings/nights and on weekends. They were also asked whether they can decide for themselves at what time they start/finish work. Regarding working in evenings/nights there was a seven point scale ranging from 'never' to 'every day'. A scale for weekend work spanned five points starting with 'never' and ending with 'every week'. For flexibility of working hours, the options to choose from when answering were 'not at all true', 'a little true', 'quite true' and 'very true'.

Time pressure at work was measured by the following statement: 'I never seem to have enough time to get everything done in my job'. The options to choose from when answering were: 'agree strongly', 'agree', 'neither agree nor disagree', 'disagree' and 'disagree strongly'. The respondents were also asked whether they are allowed to choose/chance the pace of their work. Work autonomy was further measured by asking the respondents whether they are allowed to decide how their daily work is 
organized. As regards both of these questions, a 11-point scale was used where 0 denoted 'no influence' and 10 'complete control'. Contractual job security was measured by asking the respondents whether their employment contract was of unlimited or limited duration. Subjective job security was measured by the statement: 'My job is secure'. Social support was measured by the statement: 'I can get support/help from my co-workers when needed'. Reply options for subjective work security and social support were 'not at all true', 'a bit true', 'quite true' and 'very true'. Life satisfaction was measured by asking the respondents how satisfied they are nowadays with their life as a whole. A 11-point scale was used, in which 0 denoted 'extremely dissatisfied' and 10 'extremely satisfied'.

Descriptive statistics were used to investigate the occurrence of work to family interferences, selected work characteristics and life satisfaction among working mothers, as well as among the chosen reference groups. Regarding work to family interferences, a distinction was made between mothers (and fathers) who did, and mothers (fathers) who did not, report interferences at least sometimes. The distribution of mothers who responded 'never or hardly ever', 'sometimes' and 'often or always', for the countries studied, was determined for those aspects of interference that differentiated Finnish mothers from the other mothers. With regard to work characteristics, mean values (e.g. weekly working hours), percentages of mothers who met a certain criteria (e.g. at least once a month) and percentages of mothers who responded positively to a question were determined. Mean values were used to describe life satisfaction among mothers and among the reference groups in the countries studied.

The importance of work characteristics on work to family member interferences were examined among the Finnish mothers by using ordinal regression analysis. Of particular interest were those work characteristics that were more common in Finland than in all (or almost all) other countries. All work characteristics were, however, included in the analyses. Ordinal regression analysis was also used to assess the importance of work characteristics and work to family interference on overall life satisfaction among Finnish mothers. As regards overall life satisfaction, the responses of Finnish mothers were between 5 and 10. Since very few mothers responded with 5 (one mother) or 6 (two mothers), the values 5 and 6 were grouped together with the value 7. Statistics have been calculated using weighted data (design weight). Numbers of respondents are given in a non-weighted format.

\section{Results}

\section{Work to family interference}

A close evaluation of work to family interference revealed that Finnish mothers differed from mothers in the other countries investigated in certain, although not in all, of the aspects explored (see Table 1). Tiredness outside of working hours was not 
especially common in Finland. Also, Finnish mothers worried about problems at work only a little more often than the mothers investigated on average. It was, however, found that Finnish mothers reported interferences that involve family members more often than did the mothers in the other countries. More precisely, Finnish mothers reported more often that they do not have enough time for other family members, and they also expressed more often that family members are fed up with the pressures of their work. Interferences that involve family members were common not only among Finnish mothers, but also among Finnish fathers.

Table 1. Work to family interferences among mothers (and fathers).

\begin{tabular}{lllllllll}
\hline & \multicolumn{2}{c}{$\begin{array}{c}\text { Tiredness after } \\
\text { work }\end{array}$} & \multicolumn{2}{c}{$\begin{array}{c}\text { Worry about work } \\
\text { problems }\end{array}$} & \multicolumn{2}{c}{$\begin{array}{c}\text { Job prevents from } \\
\text { giving time for family }\end{array}$} & $\begin{array}{c}\text { Family fed up with } \\
\text { pressures at work }\end{array}$ \\
& Mothers & Fathers & Mothers & Fathers & Mothers & Fathers & Mothers & Fathers \\
\hline Austria & 0.78 & $(0.71)$ & 0.64 & $(0.64)$ & 0.56 & $(0.52)$ & 0.36 & $(0.28)$ \\
Belgium & 0.73 & $(0.71)$ & 0.71 & $(0.69)$ & 0.66 & $(0.72)$ & 0.46 & $(0.50)$ \\
Denmark & 0.72 & $(0.74)$ & 0.57 & $(0.55)$ & 0.63 & $(0.66)$ & 0.39 & $(0.50)$ \\
Finland & $0.72(4)$ & $(0.70)$ & $0.62(4)$ & $(0.70)$ & $0.73(1)$ & $(0.82)$ & $0.57(1)$ & $(0.51)$ \\
France & 0.70 & $(0.66)$ & 0.69 & $(0.75)$ & 0.59 & $(0.65)$ & 0.38 & $(0.38)$ \\
Germany & 0.67 & $(0.73)$ & 0.55 & $(0.69)$ & 0.52 & $(0.71)$ & 0.36 & $(0.44)$ \\
Greece & 0.67 & $(0.62)$ & 0.52 & $(0.57)$ & 0.62 & $(0.55)$ & 0.28 & $(0.27)$ \\
Netherlands & 0.62 & $(0.65)$ & 0.48 & $(0.57)$ & 0.60 & $(0.64)$ & 0.25 & $(0.40)$ \\
Portugal & 0.61 & $(0.51)$ & 0.38 & $(0.38)$ & 0.44 & $(0.43)$ & 0.23 & $(0.18)$ \\
Spain & 0.71 & $(0.67)$ & 0.42 & $(0.58)$ & 0.62 & $(0.66)$ & 0.38 & $(0.33)$ \\
Sweden & 0.75 & $(0.78)$ & 0.56 & $(0.51)$ & 0.59 & $(0.69)$ & 0.32 & $(0.42)$ \\
United Kingdom & 0.71 & $(0.74)$ & 0.53 & $(0.59)$ & 0.51 & $(0.75)$ & 0.32 & $(0.56)$ \\
All & 0.70 & $(0.69)$ & 0.56 & $(0.61)$ & 0.59 & $(0.67)$ & 0.36 & $(0.41)$ \\
\hline
\end{tabular}

Mean value: 0 = never or hardly ever; 1 = sometimes, often or always.

Rank order for Finnish mothers is in parenthesis.

The distributions of mothers reporting work to family member interferences 'never or hardly ever', 'sometimes' and 'often or always' are shown in Figures 1 and 2. Of those mothers in Finland who experienced time-based interference (73\%), almost half experienced it often or always (35\% of all mothers). Frequent interference was more common in Finland than in the other countries (Figure 1). Of those mothers in Finland who reported strain-based interference (57\%), every fifth experienced it frequently ( $12 \%$ of all mothers). In France and Spain, the percentage of all mothers who frequently experienced strain-based interference was slightly higher, however, the percentage of mothers experiencing strain-based interference 'sometimes' was markedly lower than in Finland (Figure 2). Furthermore, the percentage of mothers reporting 'never or hardly ever' was markedly higher than in Finland. Overall, percentages of mothers who did not experience work to family member interferences were lower in Finland than in the other countries studied (Figures 1 and 2). 


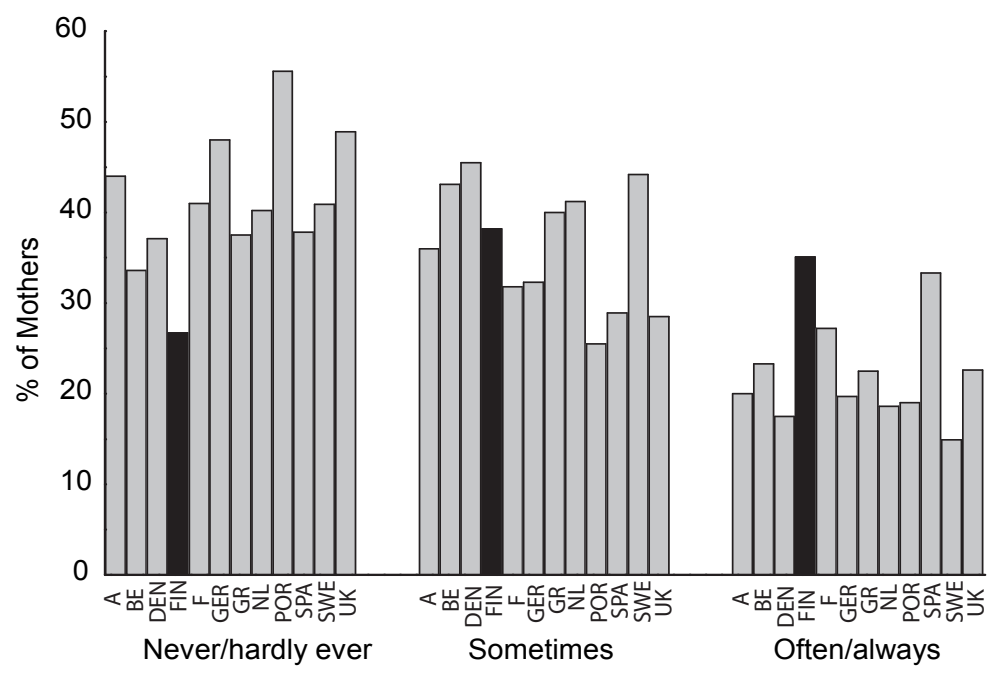

Figure 1. Time-based interference from work to family members. Columns, from left to right: Austria, Belgium, Denmark, Finland, France, Germany, Greece, the Netherlands, Portugal, Spain, Sweden and the United Kingdom.

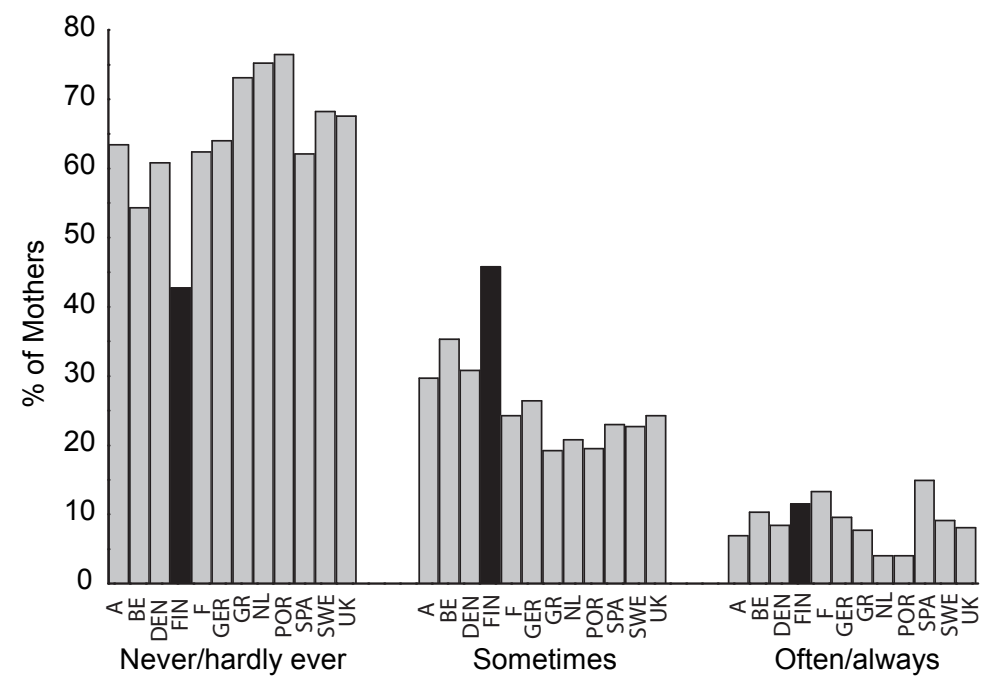

Figure 2. Strain-based interference from work to family members. Columns, from left to right: Austria, Belgium, Denmark, Finland, France, Germany, Greece, the Netherlands, Portugal, Spain, Sweden and the United Kingdom. 


\section{Work characteristics}

In line with the strong dominance of full-time work, weekly working hours in Finland were among the longest (38.3 hours; Table 2). Only in Greece and Portugal did mothers report slightly longer hours (39.7 and 38.5 hours, respectively). Finnish mothers also worked more often in the evenings and during nights than mothers in any other investigated country. Working on weekends was not quite so common among Finnish mothers, but it was more common than among mothers in general. The possibilities of deciding when to start and/or finish work were better in Finland than in most of the other countries.

Distinguishing for Finland was the high proportion (24.8\%) of work contracts with a limited duration. Irrespective of this, Finnish mothers were relatively secure about their jobs. The proportion of mothers reporting never having enough time to get everything done in their job was high (45.8\%), but, nevertheless, not quite as high as in most of the other countries. Regarding protective work characteristics, i.e. the possibility of influencing the organization of work, the possibility of changing the pace of work and the accessibility of social support, the experiences of Finnish mothers were among the most positive.

Overall, the cross-country comparison revealed only some work characteristics that negatively distinguished Finland from all, or almost all, other countries. To assess whether these work characteristics are typical for jobs in Finland in general, or for jobs of women in particular, Finnish fathers were included in the evaluations. It was observed that Finnish fathers have longer working hours compared to Finnish mothers (Table 2). The gap between the working hours (6.4 hours) is, however, smaller than between fathers and mothers on average (11.6 hours). Furthermore, more atypical working hours were reported by Finnish fathers compared to Finnish mothers. Again, the gender gap is smaller than in most of the other countries. The only work characteristics that set Finnish mothers apart from both reference groups, i.e. mothers in the other countries and Finnish fathers, was the high proportion of work contracts of a limited duration. Further, Finnish mothers reported more time pressure at work compared to that reported by Finnish fathers. Their possibilities to decide about the time to start/ finish work, organization of work and pace of work were also inferior. 
Table 2. Prevalence of work characteristics among mothers (and fathers).

\begin{tabular}{|c|c|c|c|c|c|c|c|c|c|c|}
\hline & \multicolumn{2}{|c|}{ Working hours } & \multicolumn{2}{|c|}{$\begin{array}{l}\text { Working } \\
\text { evenings/ } \\
\text { nights (\%) }\end{array}$} & \multicolumn{2}{|c|}{$\begin{array}{c}\text { Working on } \\
\text { weekends (\%) }\end{array}$} & \multicolumn{2}{|c|}{$\begin{array}{l}\text { Can decide time } \\
\text { start/finish (\%) }\end{array}$} & \multicolumn{2}{|c|}{$\begin{array}{c}\text { Not enough } \\
\text { time to do the } \\
\text { work }(\%)\end{array}$} \\
\hline & Mothers $\mathrm{F}$ & Fathers & Mothers & Fathers & Mothers & Fathers I & Mothers & Fathers I & Mothers & Fathers \\
\hline Austria & 31.3 & & 25.4 & & 38.9 & & 34.7 & & 28.4 & \\
\hline Belgium & 32.7 & & 29.3 & & 37.1 & & 29.6 & & 55.1 & \\
\hline Denmark & 36.4 & & 28.7 & & 36.4 & & 26.7 & & 49.6 & \\
\hline Finland & $38.3(3)$ & 44.7 & $44.0(1)$ & 50.3 & $38.6(4)$ & 48.7 & $36.6(2)$ & 46.2 & $45.8(8)$ & 37.8 \\
\hline France & 35.1 & & 25.7 & & 35.8 & & 54.4 & & 51.3 & \\
\hline Germany & 26.3 & & 30.5 & & 43.0 & & 22.3 & & 30.5 & \\
\hline Greece & 39.7 & & 22.2 & & 45.1 & & 10.0 & & 16.4 & \\
\hline Netherlands & 21.7 & & 30.3 & & 32.7 & & 34.8 & & 44.3 & \\
\hline Portugal & 38.5 & & 23.9 & & 28.3 & & 9.9 & & 54.9 & \\
\hline Spain & 37.0 & & 25.2 & & 35.2 & & 20.6 & & 54.6 & \\
\hline Sweden & 36.5 & & 39.9 & & 38.1 & & 33.1 & & 47.2 & \\
\hline UK & 27.4 & & 31.2 & & 29.4 & & 26.8 & & 55.2 & \\
\hline \multirow[t]{3}{*}{ All } & 32.8 & 44.4 & 30.1 & 45.9 & 36.3 & 48.2 & 29.8 & 36.6 & 45.9 & 43.1 \\
\hline & \multicolumn{2}{|c|}{$\begin{array}{c}\text { Allowed } \\
\text { to choose/ } \\
\text { change pace } \\
\text { of work }\end{array}$} & \multicolumn{2}{|c|}{$\begin{array}{l}\text { Allowed to } \\
\text { make decisions } \\
\text { regarding work } \\
\text { organization }\end{array}$} & \multicolumn{2}{|c|}{$\begin{array}{l}\text { Limited work } \\
\text { contract (\%) }\end{array}$} & \multicolumn{2}{|c|}{ Job security (\%) } & \multicolumn{2}{|c|}{$\begin{array}{c}\text { Social support } \\
(\%)\end{array}$} \\
\hline & Mothers & Fathers & s Mothers & Fathers & Mothers & Fathers & Mothers & Fathers & s Mothers & Fathers \\
\hline Austria & 7.6 & & 7.3 & & 6.8 & & 70.5 & & 78.3 & \\
\hline Belgium & 6.3 & & 7.3 & & 16.5 & & 79.6 & & 72.4 & \\
\hline Denmark & 7.3 & & 8.0 & & 9.9 & & 76.1 & & 86.3 & \\
\hline Finland & $7.4(2)$ & 7.9 & 7.7 (3) & 8.3 & $24.8(1)$ & 10.2 & $77.5(4)$ & 83.9 & $89.2(1)$ & ) 86.8 \\
\hline France & 5.9 & & 7.1 & & - & & 55.9 & & 67.7 & \\
\hline Germany & 6.7 & & 6.7 & & 11.0 & & 58.6 & & 77.8 & \\
\hline Greece & 4.8 & & 5.5 & & 11.9 & & 45.9 & & 77.9 & \\
\hline Netherlands & 6.7 & & 7.3 & & 9.6 & & 77.9 & & 82.3 & \\
\hline Portugal & 4.8 & & 5.3 & & 20.3 & & 58.0 & & 52.6 & \\
\hline Spain & 5.7 & & 6.6 & & 14.3 & & 69.7 & & 69.3 & \\
\hline Sweden & 6.7 & & 7.9 & & 13.8 & & 69.3 & & 79.6 & \\
\hline UK & 6.2 & & 7.5 & & 7.4 & & 83.5 & & 85.4 & \\
\hline$A / l$ & 6.4 & 6.8 & 7.1 & 7.4 & 13.2 & 8.00 & 68.8 & 67.6 & 76.3 & 77.6 \\
\hline
\end{tabular}

Percentages are counted for the following answering categories:

Working evenings/nights: at least several times a month

Working on weekends: at least once a month

Flexible working hours, social support, job security: quite true or very true

Not enough time to do the work: agree or agree strongly

Allowed to choose/change pace of work, allowed to make decisions regarding work organization: $0=$ no influence; $10=$ have complete control

Rank order for Finnish mothers is in parenthesis. 


\section{Work characteristics and interferences related to family members}

To what extent the work characteristics included in this study explain work to family member interferences among Finnish mothers is shown in Table 3. There are two models for both time- and strain-based interferences. In Model 1, the connection is presented separately for each work characteristic. In Model 2 only those work characteristics that attained a statistical significance in Model 1 are included. In the first stage of the analysis (Model 1), long working hours explained both time- and strain-based interference. However, in the second stage (Model 2), statistical significance was only attained for time-based interference. Regarding time-based interference, atypical working hours also attained statistical significance in Model 1. The non-existent connections in Model 2 , however, suggest that it is not necessarily atypical working hours as such but atypical hours linked with long working days that increased time-based interference. As well as long working hours, time pressure at work explained time-based interference from work to family members in Model 2, and also increased strain-based interference from work to family members. Social support from co-workers protected family members from being fed up with the pressures of mother's work (Models 1 and 2).

Table 3. Odds ratios (OR) and their $95 \%$ confidence intervals $(\mathrm{Cl})$ of work to family member interferences by work characteristics among Finnish mothers.

\begin{tabular}{|c|c|c|c|c|}
\hline & \multicolumn{2}{|c|}{ Time-based interference } & \multicolumn{2}{|c|}{ Strain-based interference } \\
\hline & $\begin{array}{c}\text { Model 1* } \\
\text { OR }(95 \% \mathrm{Cl})\end{array}$ & $\begin{array}{c}\text { Model } 2 \\
\text { OR }(95 \% \mathrm{Cl})\end{array}$ & $\begin{array}{c}\text { Model 1* } \\
\text { OR }(95 \% \mathrm{Cl})\end{array}$ & $\begin{array}{c}\text { Model } 2 \\
\text { OR }(95 \% \mathrm{Cl})\end{array}$ \\
\hline Working hours & $\begin{array}{l}1.12(1.06-1.17) \\
p<0.001\end{array}$ & $\begin{array}{l}1.14(1.07-1.22) \\
p<0.001\end{array}$ & $\begin{array}{l}1.06(1.01-1.12) \\
p=0.015\end{array}$ & $\begin{array}{l}1.04(0.98-1.11) \\
p=0.162\end{array}$ \\
\hline Work in evenings & $\begin{array}{l}1.37(1.17-1.60) \\
p<0.001\end{array}$ & $\begin{array}{l}1.21(0.96-1.54) \\
p=0.110\end{array}$ & $\begin{array}{l}1.24(1.06-1.45) \\
p=0.007\end{array}$ & $\begin{array}{l}1.06(0.84-1.35) \\
p=0.606\end{array}$ \\
\hline Work on weekends & $\begin{array}{l}1.54(1.20-2.01) \\
p=0.010\end{array}$ & $\begin{array}{l}1.30(0.88-1.92) \\
p=0.186\end{array}$ & $\begin{array}{l}1.46(1.13-1.87) \\
p=0.004\end{array}$ & $\begin{array}{l}1.48(0.99-2.19) \\
p=0.050\end{array}$ \\
\hline Flexible working hours & $\begin{array}{l}0.88(0.65-1.19) \\
p=0.414\end{array}$ & & $\begin{array}{l}1.02(0.75-1.38) \\
p=0.899\end{array}$ & \\
\hline Enough time & $\begin{array}{l}\mathbf{0 . 6 7}(\mathbf{0 . 5 0 - 0 . 9 1 )} \\
p=0.010\end{array}$ & $\begin{array}{l}\mathbf{0 . 7 0}(\mathbf{0 . 5 1}-0.97) \\
p=0.032\end{array}$ & $\begin{array}{l}0.64(0.47-0.87) \\
p=0.004\end{array}$ & $\begin{array}{l}0.63(0.46-0.89) \\
p=0.007\end{array}$ \\
\hline Able to decide regarding & & & & \\
\hline Pace of work & $\begin{array}{l}0.93(0.81-1.07) \\
p=0.328\end{array}$ & & $\begin{array}{l}1.03(0.98-1.18) \\
p=0.708\end{array}$ & \\
\hline Work organization & $\begin{array}{l}0.97(0.83-1.12) \\
p=0.689\end{array}$ & & $\begin{array}{l}1.01(0.86-1.18) \\
p=0.905\end{array}$ & \\
\hline $\begin{array}{l}\text { Work contract } \\
\text { Unlimited }\end{array}$ & ( & & & \\
\hline $\begin{array}{l}\text { Limited } \\
\text { Limited }\end{array}$ & $p=0.460$ & & $\begin{array}{l}0.64(0.29-1.34) \\
p=0.260\end{array}$ & \\
\hline Job security & $\begin{array}{l}1.15(0.82-1.59) \\
p=0.418\end{array}$ & & $\begin{array}{l}0.85(0.60-1.18) \\
p=0.329\end{array}$ & \\
\hline Social support & $\begin{array}{l}0.76(0.45-1.27) \\
p=0.301\end{array}$ & & $\begin{array}{l}0.55(0.32-0.94) \\
p=0.027\end{array}$ & $\begin{array}{l}0.56(0.32-0.88) \\
p=0.045\end{array}$ \\
\hline
\end{tabular}

Model 1 = bivariates.

Model 2 = statistically significant variables in model 1.

\footnotetext{
*Age of the mother, age of the youngest child, number of children, family type, and years of education were tested. None of these variables reached statistical significance in explaining the interferences experienced, except for age of the youngest child (Time-based interference was slightly more common among those mothers whose youngest child was 8 to 12 years old than among those mothers whose youngest child was 4 to 7 years old; $p<0.05$.).
} 
The long working days of Finnish mothers had a marked impact on time-based interference from work to family members (Table 3; Models 1 and 2). To what extent, then, can 'additional' time-based interference in Finland be explained by long working days? This was explored through a comparison with Sweden, another Nordic country with an established dual-earned dominance but with mothers who work slightly shorter daily hours. The varying strategies in family leave policies make a comparison between these two countries especially interesting. The child home care allowance was only available for the mothers investigated in Sweden for a short period in 1994 (Hiilamo and Kangas 2006). On the other hand, reduced working hours have been facilitated in Sweden by the especially flexible parental leave legislation; mothers can save part of the parental leave and use it to reduce their working hours until the child is eight years old (Pylkkänen and Smith 2004). As shown in Table 4, working hours explained a part of the difference between these countries (Model 1). However, a substantial part of the difference was unrelated to working hours (Model 2). After including strain-based interference in the analysis, the difference no longer attained statistical significance (Model 3).

Table 4. Odds ratios (OR) and their 95\% confidence intervals $(\mathrm{Cl})$ of time-based work to family member interference by country, working hours, and strain-based interference among Finnish and Swedish mothers.

\begin{tabular}{|c|c|c|c|}
\hline \multicolumn{4}{|c|}{ Time-based interference } \\
\hline & $\begin{array}{l}\text { Model } 1 \\
\text { OR }(95 \% \mathrm{Cl})\end{array}$ & $\begin{array}{l}\text { Model } 2 \\
\text { OR }(95 \% \mathrm{CI})\end{array}$ & $\begin{array}{l}\text { Model } 3 \\
\text { OR }(95 \% \mathrm{Cl})\end{array}$ \\
\hline \multicolumn{4}{|l|}{ Country } \\
\hline Finland & $2.37(1.53-3.67)$ & $2.12(1.35-3.32)$ & $1.47(0.93-2.35)$ \\
\hline Sweden & 0 & 0 & 0 \\
\hline & $p<0.001$ & $p=0.001$ & $p=0.102$ \\
\hline Working hours & & $1.09(1.06-1.12)$ & $1.06(1.03-1.09)$ \\
\hline & & $p<0.001$ & $p<0.001$ \\
\hline Strain-based int. & & & $4.19(3.07-5.70)$ \\
\hline
\end{tabular}

\section{Life satisfaction}

In Finland, there was no difference in life satisfaction among working and non-working mothers (Table 5). Overall, a somewhat higher life satisfaction was reported by working mothers as compared to non-working mothers. A clear difference was observed in the United Kingdom and France alone. In those countries where the difference was in a reverse direction (e.g. Austria), it was quite small.

In a European comparison, Finnish mothers were satisfied with their lives. Of working mothers, only Danish mothers were slightly more satisfied. Of non-working mothers, Finnish mothers were the most satisfied. Moreover, regarding Finland, both working and non-working mothers were more satisfied with their lives, compared to women who 
worked, but who did not have any children living in the same household. A positive effect of children on women in Finland was also found in an earlier study (Martikainen 2006). Furthermore, working mothers in Finland were slightly more satisfied with their life, compared to working fathers and all employees. A positive difference was also found when comparing working mothers with Finnish adults in general.

Table 5. Life satisfaction.

\begin{tabular}{|c|c|c|c|c|c|c|}
\hline & $\begin{array}{l}\text { Working } \\
\text { mothers }\end{array}$ & $\begin{array}{l}\text { Mothers at } \\
\text { home }\end{array}$ & $\begin{array}{c}\text { Working } \\
\text { childless } \\
\text { women }\end{array}$ & $\begin{array}{l}\text { Working } \\
\text { fathers }\end{array}$ & $\begin{array}{c}\text { All } \\
\text { workers }\end{array}$ & All adults \\
\hline Austria & 7.8 & 8.0 & 7.7 & 7.9 & 7.6 & 7.5 \\
\hline Belgium & 7.5 & 7.4 & 7.7 & 7.6 & 7.5 & 7.4 \\
\hline Denmark & 8.7 & 8.2 & 8.4 & 8.5 & 8.6 & 8.5 \\
\hline Finland & $8.5 \quad$ (2) & 8.5 & 7.9 & 8.3 & 8.1 & 8.0 \\
\hline France & 7.1 & 6.3 & 6.9 & 6.7 & 6.6 & 6.4 \\
\hline Germany & 7.1 & 7.2 & 6.9 & 6.9 & 7.0 & 6.8 \\
\hline Greece & 6.8 & 6.8 & 6.9 & 6.8 & 6.6 & 6.4 \\
\hline Netherlands & 7.7 & 7.7 & 7.8 & 7.7 & 7.7 & 7.6 \\
\hline Portugal & 6.0 & 6.0 & 5.9 & 5.9 & 5.8 & 5.7 \\
\hline Spain & 7.3 & 7.4 & 7.2 & 7.6 & 7.2 & 7.1 \\
\hline Sweden & 8.0 & - & 7.7 & 8.2 & 7.9 & 7.8 \\
\hline UK & 7.3 & 6.6 & 7.2 & 7.1 & 7.2 & 7.1 \\
\hline$A / l$ & 7.5 & 7.2 & 7.3 & 7.5 & 7.3 & 7.1 \\
\hline
\end{tabular}

$0=$ extremely dissatisfied, $10=$ extremely satisfied

Rank order for Finnish mothers is in parenthesis.

Numbers of mothers at home: Austria 86, Belgium 37, Denmark 12, Finland 42, France 29, Germany 84, Greece 124, the Netherlands 56, Portugal 42, Spain 55, Sweden 4, and the United Kingdom 92.

The number of working childless women varied from 94 (Denmark) to 200 (Germany), and the number of working fathers from 99 (Austria) to 198 (Sweden). In Finland, there were 150 working childless women and 188 working fathers.

The importance of work-related variables on life satisfaction among Finnish mothers is shown in Table 6. In Model 1, it is shown that life satisfaction did not depend on working hours. The importance of work characteristics to life satisfaction appeared to be weak overall, apart from flexibility of working hours, which attained statistical significance. The opportunity of deciding when to start and finish the workday was positively connected with life satisfaction. Interference from work to family members, especially strain-based interference, reduced life satisfaction (Models 2 and 3). 
Table 6. Odds ratios (OR) and their $95 \%$ confidence intervals $(\mathrm{Cl})$ of life satisfaction by work characteristics and work to family member interferences among Finnish mothers.

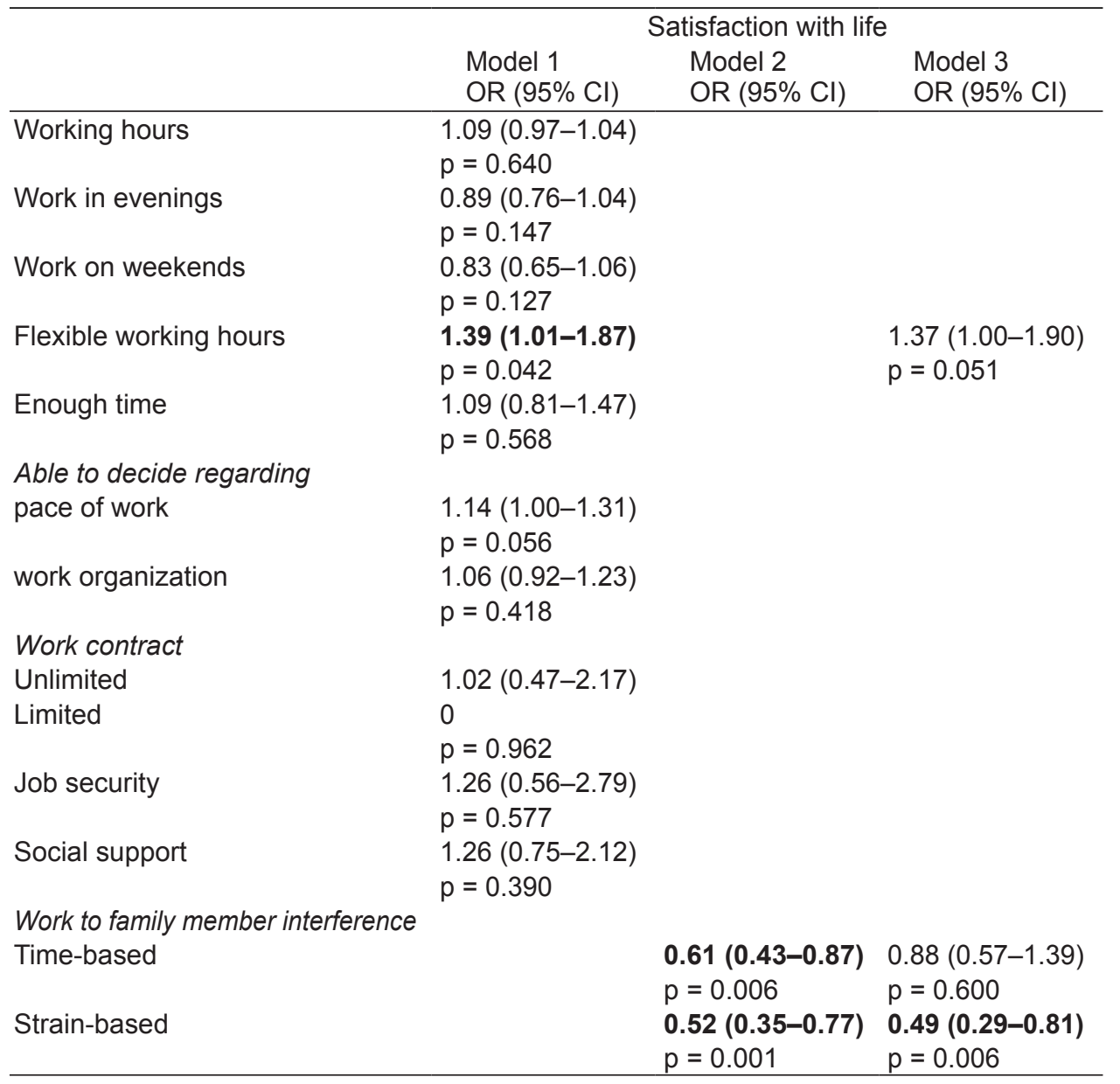

Models 1 and $2=$ bivariates.

Model 3 = statistically significant variables in models 1 and 2 .

\section{Discussion}

In this study an attempt was made to identify whether there are any particular, presumably negative, aspects in the Finnish work environment compared with other European countries. Clarification of these aspects could possibly broaden the understanding of the reasons why many mothers in Finland have chosen the option of a prolonged home care period. Overall life satisfaction of the mothers was examined as a complementary aspect. 
It was found that only a few work-related circumstances differentiated Finnish mothers from mothers in the other countries included. Both time- and strain-based interferences from work to family members were reported more often by Finnish mothers than by mothers in the other countries. Likewise, percentages of mothers who did not experience interferences from work to family members were lower than in the other countries studied. In addition, Finnish mothers differed negatively from mothers in all, or almost all, other countries with respect to the following work characteristics: long working hours, working in the evenings, during nights and on weekends, and a high proportion of work contracts of a limited duration. On the other hand, Finnish mothers had better possibilities to decide when to start/finish work and to change/choose the pace of their work as compared to mothers on average. Furthermore, they had relatively good possibilities to influence the organization of work. Social support from co-workers was also available more than among mothers in general. It is noteworthy, however, that employees in Finland have better access to support from co-workers than to support from supervisors (Eurofound 2007). The latter type of support appears to be especially important for coping with work and preventing detrimental effects of work (see Sinokki 2011). From a European perspective, time pressure at work was not especially common in Finland. However, nearly half of Finnish mothers reported time pressure at work. It explained both time- and strain-based interferences from work to family members.

Although long working hours increased time-based interference among Finnish mothers, this explained only a part of the difference between time-based interferences in Finland and Sweden. Based on related results (Table 4, Model 3), it can be concluded that, besides time spent at work, strain related to work may also prevent mothers from giving time to family members. With respect to time pressure and social support at work, the foremost explanations for strain-based interference among Finnish mothers (see Table 3), Finnish mothers did not, however, differ negatively from Swedish mothers. Overall, except for longer working hours, it cannot be concluded from these results why Finnish mothers reported more time-based interference from work to family members than did the Swedish mothers. A way to resolve the issue could possibly be to increase the number of working conditions that are considered. Conversely, some of the reasons for the additional interference experienced by mothers in Finland might be unrelated to work. For example, the ideals of mothers regarding the time that they should spend with other family members might vary between the countries.

Somewhat shorter working hours could clearly decrease the time-based interference from work to family members experienced by Finnish mothers. A study of mothers of young school children in Finland indicated, however, that there are certain work domain obstacles that hinder mothers from reducing working hours (Lehto and Sutela 2008). Firstly, a part of the mothers thought that the nature of their work is such that a reduction in working time would be inappropriate. Some of the mothers were also concerned that workload would remain the same, despite the reduced working hours. 
On the basis of the present results, such an intensification of work could increase interference from work to family members (Table 3). Lehto and Sutela (2008) also found that some of the mothers were concerned that a reduction in working hours would endanger their position in the workplace. To increase the appeal of shorter working hours and to avoid negative side effects related to a reduction in work time, work should be reorganized so that reduced working hours would not lead to a greater intensity of work, endanger a mother's attachment to her job, or weaken her possibilities of career progression.

Among Finnish mothers, interference related to family members, especially a feeling that family members are fed up with the pressures of one's work, was negatively connected to life satisfaction. With the exception of flexible working hours, work characteristics appeared to be practically unimportant. The lack of a connection between unfavourable working conditions and life satisfaction observed here can possibly be explained, at least to some degree, by concepts from a theory of social comparison (e.g. Festinger 1954; Emmons and Diener 1985). That is, people do not assess their life situation in isolation from others. They instead compare their situation with the situation of people around them, i.e., with a peer group. It is thus the relative situation rather than the absolute one that determines a person's life satisfaction. The interest in the present study was primarily on such working conditions that have become more common during the last few decades. Perhaps, due to the prevalence of these conditions, mothers considered them as norms rather than exceptions. That is, many people had a corresponding work condition, and a comparison with others did not therefore lead to a reduction of life satisfaction.

With respect to life satisfaction, the relative situation of mothers in Finland was better than that of mothers in any other country included. Whether or not a mother participated in paid work did not change this circumstance. Finnish childcare policies have most probably contributed to the favourable situation. The home care period, linked with a compensation that covers a considerable part of the loss of earnings, is among the longest in Europe. Those mothers who are not entitled to earnings-related compensation are entitled to flat-rate compensation. Mothers who have a work contract also have a job guarantee during the whole three years of the family leave period. After the parental leave period, lack of childcare does not restrict the choices of fulltime paid work, as in many other countries, in which mothers are forced to choose between a prolonged home care period, sometimes with no monetary compensation or job guarantee, and a part-time job. On the whole, the relatively high life satisfaction among both working and non-working mothers in Finland can possibly be seen as an indication that Finnish childcare policies have succeeded in their aim of promoting a free choice between various work-care situations, as well as promoting the financial circumstances of the mothers. 


\section{Summary and conclusions}

Detrimental effects of work involving other family members were reported more commonly by Finnish mothers than by mothers in the other countries studied. Almost three quarters of mothers in Finland felt, at least sometimes, that they do not have enough time for other family members because of work, and more than half felt that family members are fed up with the pressures of their work. On average, Finnish mothers reported longer working hours than mothers in most of the other countries studied. Atypical working times, as well as work contracts with a limited duration, were also more common in Finland than in all, or almost all, other countries. Of these work characteristics, long working hours explained time-based interference from work to family members.

Compared to mothers in most of the other countries included, Finnish mothers had better possibilities to decide when to start/finish work, change/choose the pace of their work and influence the organization of work. More social support from co-workers was available for the mothers, compared to mothers in the other countries. Furthermore, subjective job insecurity among mothers was not especially common in Finland. Time pressure at work was frequent, even if not quite as frequent as in many other countries. Time pressure at work increased both time- and strain-based interferences from work to family members. As regards strain-based interference, a protective effect was related to social support from co-workers.

On the basis of the results obtained here it seems that slightly shorter working hours could decrease time-based interference from work to family members. Both timeand strain-based interferences could be decreased by reducing time pressure at work. Furthermore, obtaining social support from co-workers can protect a mother's family members from any detrimental effects related to pressures at work. It would therefore be important to ensure that mothers have adequate opportunities to reduce their working hours, that they are not affected by continuous time pressure at work, and that they have adequate support, especially, in cases when the qualitative or quantitative demands of the job surpass their own skills or resources. Besides legislative aspects, challenges are thus set to the managers of organizations in which mothers work.

In summary, certain work-related circumstances that could have increased the appeal of the long home care periods in particular in Finland were revealed by this study. Such circumstances are, especially, interferences from work to family members. These interferences were, however, common not only among mothers in Finland, but also among fathers. Perhaps interferences experienced by fathers could be regarded as additional work-related circumstances that could increase the attraction of prolonged home care periods. It could be thought that, especially in families where both parents feel that work participation interferes with family roles, a practical solution is that the parent who earns less (typically the mother, see Korkeamäki and Kyyrä, 2005) withdraws temporarily from the labor force. It remains to be seen whether these 
interferences affecting family members have a real-life influence on the decisions of Finnish mothers to stay at home for a somewhat longer period. A longitudinal approach would be needed to more conclusively discern whether these interferences from work to family members actually increase the probability of mothers in Finland choosing a child home care allowance, and whether the effect depends on certain qualities of the mother (e.g. ambitions related to career progression).

Life satisfaction among Finnish mothers was practically independent from circumstances related to work, except for interference from work to family members and flexibility of work time. It also made no difference whether a mother participated in paid work or not. The fact that both working and non-working mothers in Finland were satisfied with their lives can perhaps be seen as an indication that Finnish childcare policies have succeeded in their aim of promoting a free choice for women between work and care roles.

\section{Limitations}

There are certain reasons why findings regarding the working conditions within individual countries should be treated with caution. Firstly, the numbers of working mothers were low, especially in some of the countries investigated. Secondly, consideration was restricted only to those mothers who worked at the time the data were collected. In the three Southern European countries and Belgium, a considerable part of mothers with a non-working status had never done any paid work. However, in all of the countries included, a majority of the non-working mothers had worked earlier in their life (data of this study). A key question, then, is whether the non-participation situations had been affected by negative perceptions related to the earlier work experiences of these mothers. For countries in which non-participation in paid work was common among the mothers, this circumstance could influence results so that perceptions related to work appear less negative than they were among mothers in general. Some of the questions regarding working conditions, that is, weekly working hours and two aspects of work autonomy (pace and organization of work), were also asked of those mothers who did not work at the time the data were collected. An inclusion of those mothers in the analyses would have changed the results so that they became more negative; however, the rank orders for Finnish mothers would not have changed.

Even if the two limitations described may cast some doubts on whether one can generalise the results regarding work-related perceptions within the countries investigated, they should not have any bearing on the primary finding of this study. Firstly, negative effects from work to family members were reported more commonly by Finnish mothers than by mothers in any other investigated country, regardless of the number of non-working mothers in these countries. Secondly, interferences from work to family members were common not only among the mothers in Finland, but also among the fathers, i.e. among both parents. 


\section{References}

Berger, Eva M. 2009. Maternal employment and happiness: The effect of nonparticipation and part-time employment on mothers' life satisfaction. SOEPpapers [online], 178. [cited in May 2011]. Berlin: Deutches Institut für Wirtschaftsforschung. Available from: $\leq$ http://www.diw.de/documents/publikationen/73/diw 01.c.98011. de/diw sp0178.pdf $\geq$

Boye, Katarina. 2011. Work and well-being in a comparative perspective - the role of family policy. European Sociological Review 27(1): 16-30.

Bradshaw, Jonathan and Naomi Finch. 2002. A comparison of child benefit packages in 22 countries. Department for Work and Pensions, Research Report, No. 174. Leeds: Corporate Document Services.

Cooper, Cary. 2007. Mental well being at work. International Journal of Public Health 52: $131-2$.

Diener, Ed, Shigehiro Oishi and Richard E. Lucas. 2003. Personality, culture, and subjective well-being: Emotional and cognitive evaluations of life. Annual Review of Psychology 54: 403-25.

Emmons, Robert A. and Ed Diener. 1985. Factors predicting satisfaction judgments: A comparative examination. Social Indicators Research 16(2): 157-67.

Eurofound (European Foundation for the Improvement of Living and Working Conditions). 2007. Work-related stress. [online]. [cited in May 2011]. Available from: $\leq \mathrm{http}$ //eurofound.europa.eu/ewco/reports/TN0502TR01/TN0502TR01.pdf $>$

Eurostat. 2005. Gender gaps in the reconciliation between work and family life. Statistics in focus, population and social conditions (by Christel Aliaga), 4/2005 [online]. [cited in May 2011]. Available from: $\leq$ http://epp.eurostat.ec.europa.eu/cache/ITY OFFPUB/ KS-NK-05-004/EN/KS-NK-05-004-EN.PDF>

Fagan, Colette and Brendan Burchell. 2002. Gender, jobs and working conditions in the European Union. [online]. European Foundation for the Improvement of Living and Working Conditions. [cited in May 2011]. Luxembourg: Office for Official Publications of the European Communities. Available from: $\leq \mathrm{http}: / / \mathrm{www}$.eurofound. europa.eu/pubdocs/2002/49/en/1/ef0249en.pdf>

Festinger, Leon. 1954. A theory of social comparison processes. Human Relations 7(2): $117-40$.

Gornick, Janet C. and Marcia K. Meyers. 2003. Families that work: Policies for reconciling parenthood and employment. New York: Russell Sage Foundation.

Greenhaus, Jeffrey H. and Nicholas J. Beutell. 1985. Sources of conflict between work and family roles. Academy of Management Review 10(1): 76-88.

Greenhaus, Jeffrey H. and Gary N. Powell. 2006. When work and family are allies: A theory of work-family enrichment. Academy of Management Review 31(1): 72-92.

Hiilamo, Heikki and Olli Kangas. 2006. Trap for women or freedom to choose? Political frames in the making of child home care allowance in Finland and Sweden. Publications of the Department of Social Policy, A: 18/2006. Turku: University of Turku.

Hood, Christopher. 1995. The "New public management" in the 1980s: Variations on a theme. Accounting, Organizations and Society 20(2-3): 93-109. 
Kainulainen, Sakari. 1998. Elämäntapahtumat ja elämään tyytyväisyys eri sosiaaliluokissa. [Life events and satisfaction with life in different social classes]. Dissertation. Kuopio: University of Kuopio.

Kauppinen-Toropainen, Kaisa, Elina Haavio-Mannila, Irja Kandolin and Marja Simonsuuri-Sorsa. 1983. Naiset ja työ [Women and work]. Katsauksia 57. Helsinki: Finnish Institute of Occupational Health.

Koivumäki, Jaakko. 2005. Uusi julkisjohtaminen ja työelämän muutokset 1990-luvulla - lähenivätkö julkisen ja yksityisen sektorin palkansaajien työelämäkokemukset? [New public management and the changes of working life in the 1990s - did the working life experiences of civil servants and private sector employees converge?] Hallinnon tutkimus [online], 3: 14-31. [cited in May 2011]. Available from: $\leq \mathrm{http}: / /$ elektra.helsinki.fi/se/h/0359-6680/24/3/uusijulk.pdf $>$

Kompier, Michiel, Jan Fekke Ybema, Julia Janssen and Toon Taris. 2009. Employment contracts: Cross-sectional and longitudinal relations with quality of working life, health and well-being. Journal of Occupational Health 51: 193-203.

Korkeamäki, Ossi and Tomi Kyyrä. 2005. The gender wage gap and sex segregation in Finland. Finnish Economic Papers 2/2005 [online]. [cited in May 2011]. Helsinki: Government Institute for Economic Research (VATT). Available from: $\leq$ http://www. taloustieteellinenyhdistys.fi/images/stories/fep/fep22005 korkeamaki.pdf $>$

Lammi-Taskula, Johanna. 2004. Äidit työmarkkinoilla - kahden kerroksen väkeä? [Mothers in the labour market - upstairs and downstairs people?]. Yhteiskuntapolitiikka 69(2): 202-6

Lammi-Taskula, Johanna, Minna Salmi and Sanna Parrukoski. 2009. Työ, perhe ja tasa-arvo. [Employment, family and gender equality]. Reports of Ministry of Social Affairs and Health, 2009:55. Helsinki: Ministry of Social Affairs and Health.

Lazarus, Richard S. and Susan Folkman. 1984. Stress, appraisal, and coping. New York: Springer Publishing.

Lehto, Anna-Maija, Maija Lyly-Yrjänäinen and Hanna Sutela. 2005. Pysyvän työn toivossa. Määräaikaisten työsuhteiden käytöstä ja kokemisesta. [In hope of a permanent job. On the utilisation of fixed-termed employment and how they are experienced]. Labour force policy studies, 291. Helsinki: Ministry of Labour.

Lehto, Anna-Maija and Hanna Sutela. 2008. Työolojen kolme vuosikymmentä. Työolotutkimusten tuloksia 1977-2008. [Three decades of working conditions. Results from quality of work life surveys 1977-2008]. Helsinki: Statistics Finland.

Major Virginia S., Katherine J. Klein and Mark G. Ehrhart. 2002. Work time, work interference with family and psychological distress. Journal of Applied Psychology 87(3): 427-36.

Mauno, Saija. 1999. Job insecurity as a psychosocial job stressor in the context of the work-family interface. Jyväskylä studies in education, psychology and social research, 156. Jyväskylä: Jyväskylä University.

Martikainen, Liisa. 2006. Suomalaisten nuorten aikuisten elämään tyytyväisyyden monet kasvot. [The many faces of life satisfaction among young adults in Finland]. Jyväskylä studies in education, psychology and social research, 287. Jyväskylä: Jyväskylä University. 
Martikainen, Liisa. 2009. The many faces of life satisfaction among Finnish young adults. Journal of Happiness Studies 10(6): 721-37.

Matysiak, Anna, Ariane Pailhé, Anne Solaz and Daniele Vignoli. 2010. Does an improvement in work-family balance increase life satisfaction? Evidence from 27 European countries [online]. [cited in May 2011]. Paper presented at the European Population Conference, Vienna, 1-4 September 2010. Available from: $\leq \mathrm{http}: / /$ epc2010.princeton.edu/download.aspx?submissionId $=100807>$

Minkov, Michael. 2009. Predictors of differences in subjective well-being across 97 nations. Cross-Cultural Research 43(2): 152-79.

OECD. 2005. Babies and bosses: Reconciling work and family life. Canada, Finland, Sweden and the United Kingdom. Volume 4. Paris: OECD.

OECD. 2007. Babies and bosses - reconciling work and family life: A synthesis of findings from OECD countries. Volume 5 [online]. [cited in May 2011]. Paris: OECD. Available from: $\leq$ http://www.oecd.org/document/19/0,3746,en_2649 348 $1939651501 \_1 \quad 1 \quad 1 \quad 1,00 . \mathrm{html}>$

OECD. 2010. Employment Outlook. Statistical Annex. [online]. [cited in May 2011]. Available from: $\leq$ http://www.oecd.org/dataoecd/30/33/43272221.pdf $>$

Paoli, Pascal and Damien Merllié. 2001. Third European survey on working conditions 2000. European foundation for the improvement of living and working conditions. [online]. [cited in May 2011]. Luxembourg: Office for Official Publications of the European Communities. Available from: $<\underline{\mathrm{http}} / / / \mathrm{www}$.eurofound.europa.eu/ pubdocs/2001/21/en/1/ef0121en.pdf >

Parent-Thirion, Agnès, Enrique F. Macías, John Hurley and Greet Vermeylen. 2005. Fourth European working conditions survey. European foundation for the improvement of living and working conditions. [online]. [cited in May 2011]. Luxembourg: Office for Official Publications of the European Communities. Available from: $\leq \mathrm{http}: / / \mathrm{www}$. eurofound.europa.eu/pubdocs/2006/98/en/2/ef0698en.pdf $>$

Pavot, William and Ed Diener. 1993. Review of the satisfaction with life scale. Psychological Assessment 5(2): 164-72.

Pylkkänen, Elina and Nina Smith. 2004. The impact of family-friendly policies in Denmark and Sweden on mothers' career interruptions due to childbirth. IZA discussion paper, No. 1050. Bonn: Institute for the Study of Labor.

Salmi, Minna, Johanna Lammi-Taskula and Johanna Närvi. 2009. Perhevapaat ja työelämän tasa-arvo. [Family leaves and equality in work life]. Työ ja yrittäjyys, 24/2009. Helsinki: Ministry of Employment and the Economy.

Scherer, Stefani. 2009. The social consequences of insecure jobs. Social Indicators Research 93(3): 527-47.

Shin, Doh C. and Dan M. Johnson. 1978. Avowed happiness as an overall assessment of the quality of life. Social Indicators Research 5(1): 475-92.

Sinokki, Marjo. 2011. Social factors at work and the health of employees. Studies in social security and health, 115. Helsinki: Kela, Research Department.

Statistics Finland. 2005. Kun epätyypillisestä tuli tyypillistä [When atypical became typical]. [online]. [cited in May 2011]. Helsinki: Statistics Finland. Available from $\leq$ http://www.stat.fi/tup/tietoaika/tilaajat/ta $03 \quad 05$ epatyypillinen.html $>$ 
Statistics Finland. 2011. Työvoimatutkimus. Työsuhteet ja työajat vuonna 2010. [Labour force survey. Employment relationships and working times in 2010]. [online]. [cited in June 2011]. Helsinki: Statistics Finland. Available from <http://www.stat.fi/til/ tyti/2010/15/tyti_2010_15_2011-06-07_fi.pdf $>$

Steiber Nadia. 2009. Reported levels of time-based and strain-based conflict between work and family roles in Europe: A Multilevel Approach. Social Indicators Research 93(3): 469-88.

Tammelin, Mia. 2009. Working time and family time. Experiences of the work and family interface among dual-earning couples in Finland. Jyväskylä studies in education, psychology and social research, 355. Jyväskylä: Jyväskylä University.

van Rijswijk, Karen, Marrie H. J. Bekker, Christel G. Rutte and Marcel A. Croon. 2004. The relationships among part-time work, work-family interference and well-being. Journal of Occupational Health Psychology 9(4): 286-95.

Virtanen, Pekka, Jussi Vahtera, Mika Kivimäki, Jaana Pentti and Jane Ferrie. 2002. Employment security and health. Journal of Epidemiology and Community Health 56(8): 569-74.

Wallace, Claire, Florian Pichler and Bernadette C. Hayes. 2007. First European quality of life survey: quality of work and life satisfaction. European foundation for the improvement of living and working conditions. [online]. [cited in May 2011]. Luxembourg: Office for Official Publications of the European Communities. Available from: $<\underline{\text { http://www.eurofound.europa.eu/pubdocs/2006/95/en/1/ef0695en.pdf }>}$ 